\title{
1. STRUCTURE AND SPATIAL TYPOLOGY OF THE WORLD POPULATION TODAY
}

\subsection{INITIAL REMARKS}

The rapid demographic growth which began after WWII has become one of the key global problems. Population's reproduction has revealed unique qualitative changes referred to as a demographic transition. Those lead from traditional to modern reproduction which is reflected mainly in a decrease of the number of children in a family, the extension of life expectancy and the numerical balancing between basic age groups. The processes of demographic modernisation which began between the 17th and the 19th c. in the countries of Western and Northern Europe have later expanded onto other regions of the world gaining their mature form in the 20th c. Those changes have been explained in the theory of demographic transition formulated in mid-1940s by F. Notestein (Notestein 1945; Okólski 1990). Contemporary empirical studies of demographic changes in highly industrialised countries served as the basis for the construction of the theory of the second demographic transition (Van de Kaa 1987, 2003; Coleman 2002; Kurek 2008) in which general fertility drops below the level of demographic renewal.

A new demographic image of the modern world formed as a result of postWWII demographic changes. The main goal of the study is to present comprehensively the main features of the new demographic image and to synthesise them considering the influence of geographical location, natural conditions and the social-economic and social-cultural situation on the demographics of the countries of the world. I conducted a detailed analysis, which covers 184 countries, of the spatial distribution of the population, its development and reproduction as well as the demographic structure as of 2006. 
Finally, I present a spatial demographic typology as a summary of the entire problem area. This study is mostly based on reliable demographic information acquired from official publications of individual countries, international organisations and institutions (Encyklopedia Świat i Polska 2007, 2006). I have also included selected international statistical data published by GUS (Central Statistical Office). Within the course of my study, I refer to analyses and diagnoses of the world demographic situation on which many researchers focus. Some of the most noteworthy publications include those by: B. Urłanis (1966), L. Kosiński (1967), A. Jagielski (1974), A. Maryański (1977), H. Jones (1993), R.-J. Thumerelle (1996), J.I. Clarke (1998), T. Kaczmarek, T. Koralewski, R. Matykowski (1998), or D. Jędrzejczyk (2001).

\subsection{SPATIAL STRUCTURE OF POPULATION}

The spatial structure of the world population and its changes are shaped by environmental, demographic, social-economic, political and historical conditions. It is the product of a complex system of mutual relations between the society and geographical space. As a result of those factors, the distribution of the world population, which in 2006 reached 6.5 billion people, has been excessively irregular in individual countries $(\mathrm{V}=372.4 \%)^{1}$. At the same time, there is a general tendency for the number of countries to decrease as their populations increase (Fig. 1). This is visible in a very strong positive asymmetry $(\mathrm{A}=8.38)$ and slenderness $(\mathrm{K}=75.45)$ of the distribution of the populations of individual countries which possesses a strong positive correlation to their area $\left(r=0.824\right.$; substantial correlation of 0.01 bilaterally $^{2}$; Fig. 2). At the same time, one may notice a paradox where there is no significant correlation between the size of said populations and the level of urbanisation expressed through the share of urban population within the total population $(\mathrm{r}=-0.022)$. The huge disproportion within the spatial distribution of the world population is further exemplified by the fact the $25 \%$ of all studied countries have a population of no more than 2.2 million while $75 \%$ - of less than 23.3 million. Also, it is worth noticing that population of more than half of the countries (56.0\%) is less than 10 million people, while their share in the world population is small, slightly exceeding $5 \%$ the $(5.32 \%)$.

\footnotetext{
${ }^{1}$ In the text, I adopted the following symbols: V - normalised coefficient of variation, $\mathrm{A}$ - normalised asymmetry coefficient, $\mathrm{K}$ - normalised kurtosis coefficient, $\mathrm{r}$ linear correlation coefficient. Those measures, as well as other measures used in this study, were mostly calculated using the professional statistical package SPSS 14.0 for Windows.

${ }^{2}$ Calculated for algorithms of values of both variables.
} 


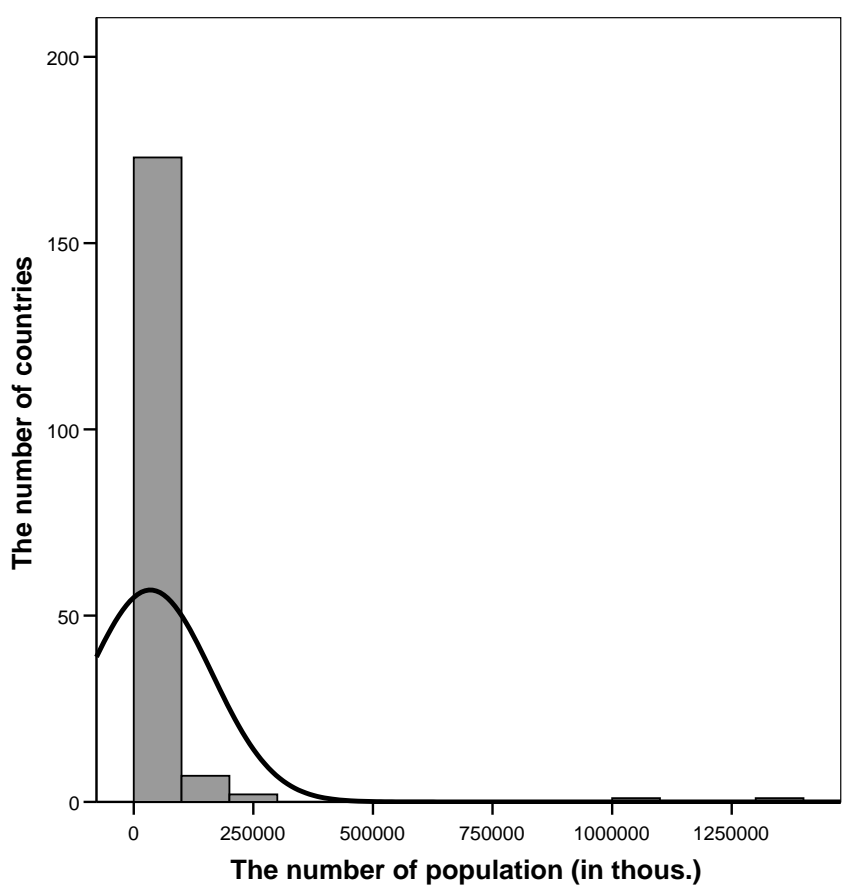

Fig. 1. The relationship between the number of countries and their population potential (the curve corresponds to normal distribution)

From the point of view of population power, world countries with population in excess of 100 million are the most important (Fig. 3). This category includes 11 countries with diverse population potential according to which they may be classified in the following descending order: 1. China (1,303.7 million people), 2. India (1,092.96.), 3. USA (296.4) 4. Indonesia (219.9), 5. Brazil (184.2), 6. Pakistan (150.5), 7. Russia (143.5), 8. Bangladesh (136.6), 9. Nigeria (128.2), 10. Japan (127.8) and 11. Mexico (103.1). The combined population of those countries constitutes $61 \%$ of the total world population. In addition, among all 184 studied countries, Poland was classified 31st in terms of population potential (38.2 million). Argentina and Tanzania have similar populations to Poland.

The world population displays a characteristic tendency for creating large clusters. Today, one can identify seven developed clusters with an international scope: 1. East Asian (China, Japan, South and North Korea, Taiwan), 2. South-East Asian (Indochina, the Philippines and the Malay Archipelago), 3. Indian (India, Pakistan and Bangladesh), 4. European, 5. North American (USA), 6. Brazilian, 7. Nigerian. There is also a number of regional population clusters formed within individual countries, e.g. eastern Brazil, southern Nigeria, the valley of the Nile and Java. Another category of large urbanised population 
clusters includes large urban agglomerations seven of which possess a population in excess of 10 million: Shanghai, Bombay, Beijing, Delhi, Tokyo and Jakarta. At the same time, researchers have been observing the formation of many new clusters of cross-border nature (e.g. in Eastern Africa, Middle America and South America). It must be stressed that the studied population clusters usually form within areas with favourable natural conditions which facilitate settlement processes. They exist in various cultures representing regions with diverse levels of development and domination of different sectors of the economy.

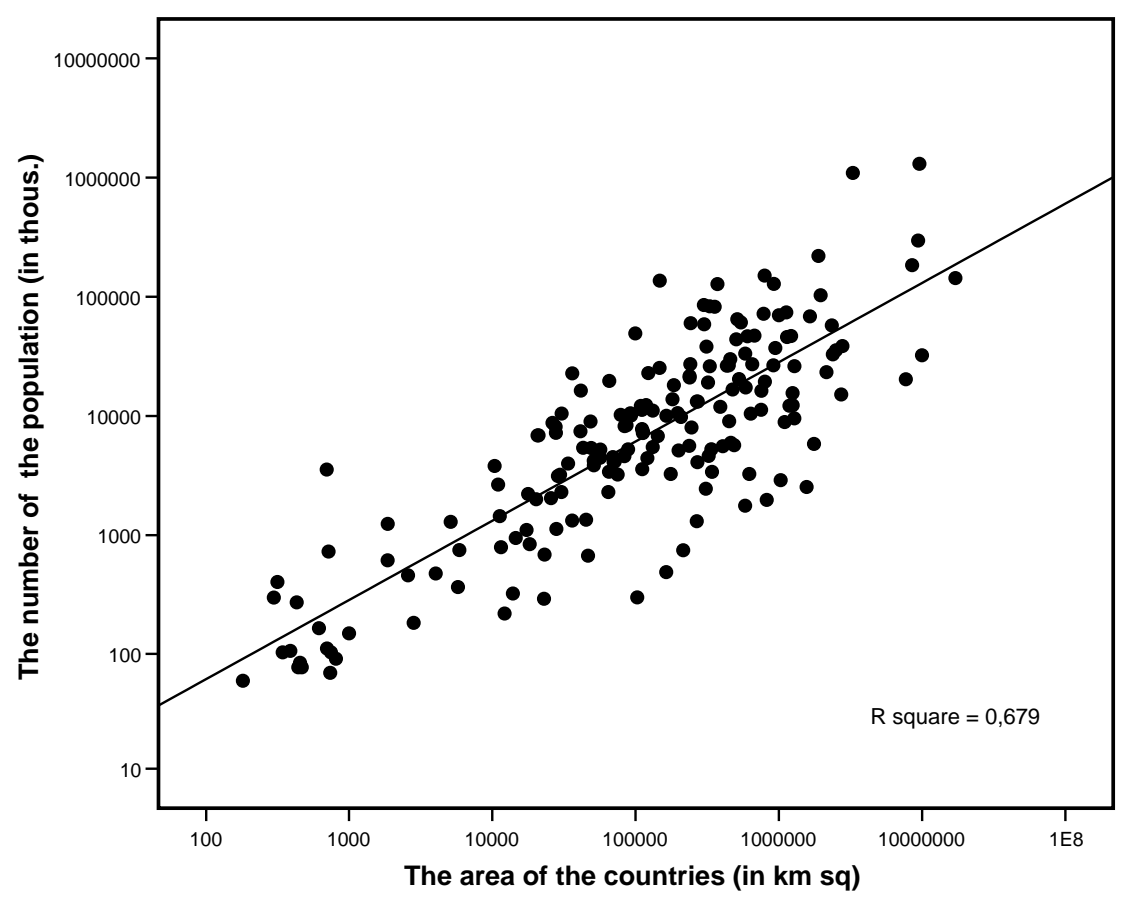

Fig. 2. The relationship between the size of the population and the area of the country

The least populated countries in the world include countries located in polar regions, deserts or semi-deserts, alpine or tropical regions, as well as small city-states or island states and a number of countries located near global countries. 


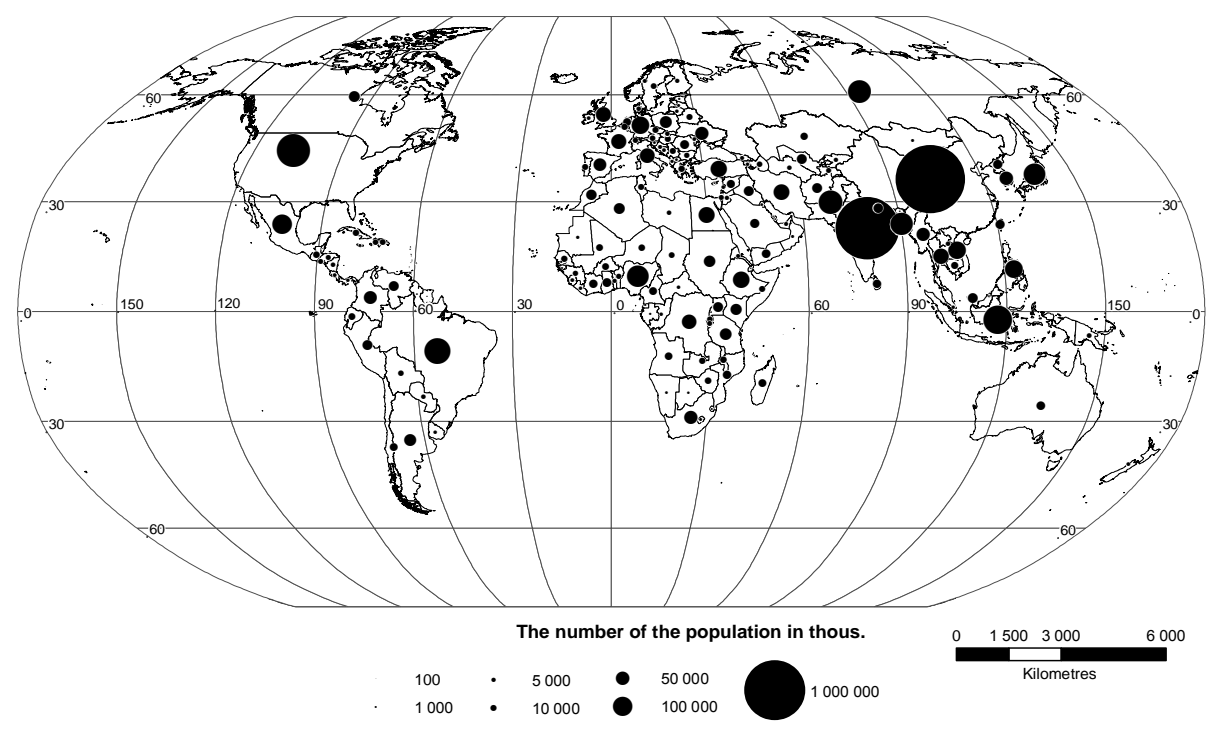

Fig. 3. Distribution of the world population

Population density is an expression of overall relationships between the society and geographical space. Its distribution in the studied countries is moderately negatively correlated to their areas $(r=-0.590)$ and it does not display any correlation to population $(r=-0.029)$ or the level of urbanisation $(\mathrm{r}=0.019)$. At the same time, it possesses similar general characteristics as the distribution of population discussed earlier. The most significant is a general trend for the number of countries to drop with the rise in the density of their populations. In $25 \%$ of all countries, population density does not exceed 26.5 people per sq $\mathrm{km}$, in $50 \%-65.7$ people per sq $\mathrm{km}$ and in $75 \%-134.5$. Eight countries possess very high population density exceeding 500 people per sq $\mathrm{km}$ : Singapore (max. 5,083.7 people/sq km), Malta, Bahrain, Maldives, Bangladesh, Mauritius, Barbados and Taiwan. On the other extreme, there are 11 countries with very low population density of no more than 5 people per sq $\mathrm{km}$. This group includes: Gabon, Guyana, Libya, Canada, Botswana, Surinam, Iceland, Mauritania, Australia, Namibia and Mongolia (at least 1.62 person per sq km). The spatial structure of population density in the world is generally similar to the territorial distribution of populations of countries discussed earlier.

The degree of spatial concentration of the world population must be considered high taking into account the concentration relation $(\eta=0.6495)$ and the defined shape of the concentration curve (Fig. 4). Furthermore, within land areas, there is a significant separation of zones with considerably different levels of population concentration (Fig. 5). High concentration areas are areas inhabited by $60 \%$ of the general population but their area constitutes only $14.8 \%$ of the 
total area of a given country. They include agricultural regions of Eastern, South-Central and South Eastern Asia and the most urbanized regions of Western and Central Europe (Great Britain, Belgium, the Netherlands, Denmark, Luxembourg, Germany, Switzerland, Italy, the Czech Republic, Poland). The zone also includes several countries located in Africa, e.g. Nigeria, Gambia, Rwanda, Burundi as well as in Middle America, e.g. the Dominican Republic, Haiti, Salvador, Jamaica. City-states and island states spread around the world are also a characteristic for the zone. Population density of the entire zone exceeds 115 people per sq $\mathrm{km}$.

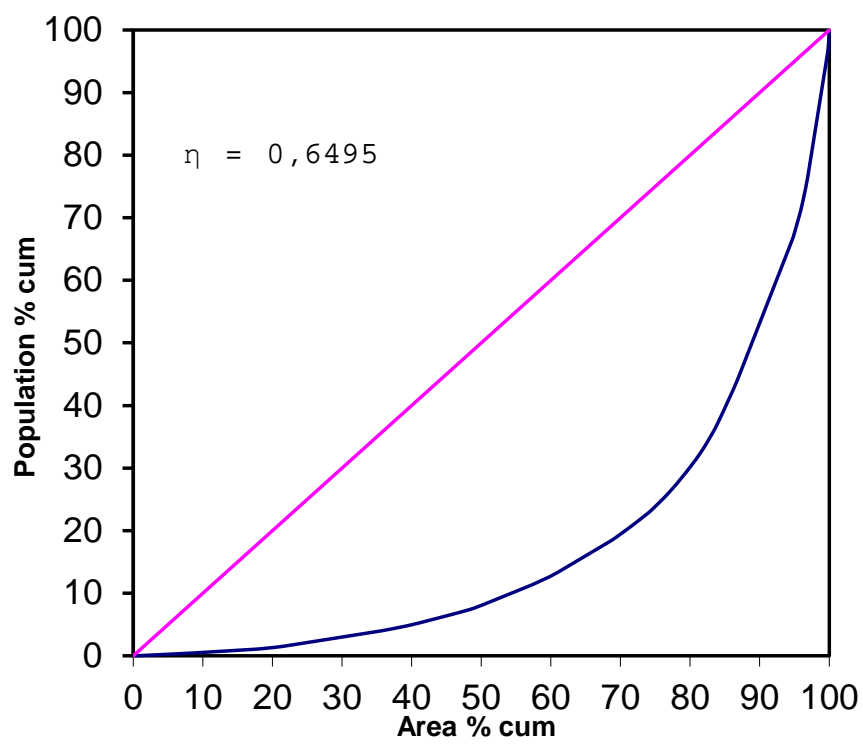

Fig. 4. Spatial concentration of the world population

Low population density, on the other hand, below 23 people per sq $\mathrm{km}$, is a characteristic feature of the lowest population concentration zone. In this case, as much as $54.3 \%$ of the total area of the countries is occupied by just $10 \%$ of the world population. This zone includes countries which area is occupied completely or to a large extent by ice sheets, tundra or taiga, large deserts, semideserts or steppe, tropical or alpine regions (e.g. Canada, Russia, Iceland, Namibia, Mongolia, Kazakhstan, Australia, Guiana, Congo, Bolivia, Peru). 


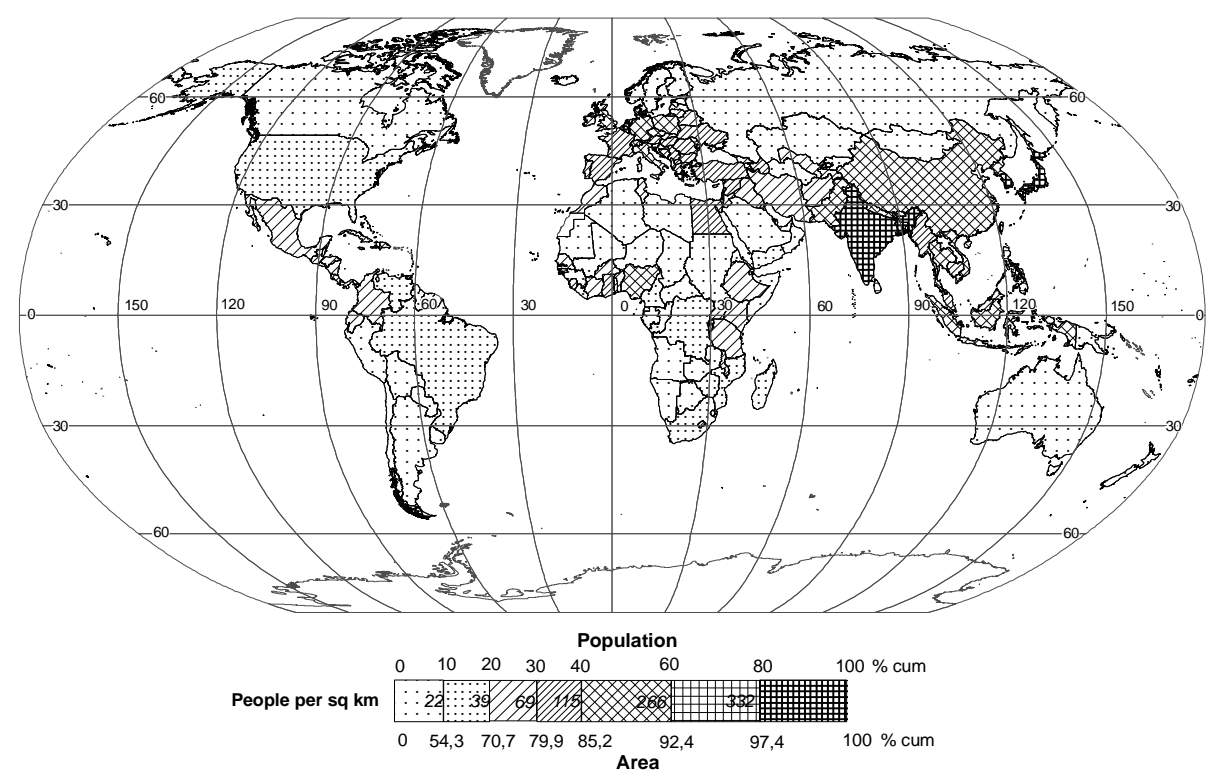

Fig. 5. Spatial concentration of the world population

\subsection{POPULATION'S SPATIAL TYPOLOGY ACCORDING TO DEMOGRAPHIC FEATURES}

The demographic overview of the world today presented above is very diverse. To synthesise it, one requires a spatial typology of the population of the countries (184) according to their demographic features. For typology reasons, I have selected 19 variables $^{3}$ which offer comprehensive illustration of the demographic situation taking into consideration the spatial structure of the population, permanent migrations, demographic development and natural movement and the structure of the population according to sex and age. All diagnostic features were subject to statistical standardisation while two of them $(1,2)$ displaying high asymmetry were subject to logarithmic transformation. For typology reasons, I have chosen the k-means clustering method which had

${ }^{3}$ 1. Population size; 2. Population per $1 \mathrm{sq} \mathrm{km}$; 3 . Share of urban population (\%); 4. Migration net $(\% o)$; 5. Annual population growth rate $(\% o) ; 6$. Number of family members; 7. Birth rate (\%o); 8. Mortality rate (\%o); 9. Infant mortality rate (\%o); 10. Average life expectancy - men; 11. Average life expectancy - women; 12. Natural increase (\%o); 13. Total Fertility Rate; 14. Masculinisation; 15. Share of children (\%); 16. Share of adults (\%); 17. Share of elderly people; 18. Demographic dependency ratio; 19. Demographic ageing ratio. 
proved successful during many of my previous studies. This way I was able to identify eight best separated clusters which may be associated with individual types of states (Fig. 6). Names of individual types are derived from their most significant diagnostic features.

Type 1 - very high birth and mortality rates. Type 1 occurs in many (33) countries with relatively low population density, occupying dense areas mainly in Central, Eastern and Western Africa. Those countries display very high birth and fertility rates as well as high general mortality related to exceptionally high infant mortality rate. This is often associated with low average life expectancy for both men and women with excessive mortality among women. At the same time, this type has high demographic growth resulting from very high natural increase which is, however, in line with low international migration net. High birth rates results in this case in high share of children and low share of both adults and elderly people as well as high level of demographic dependency and low level of population ageing.

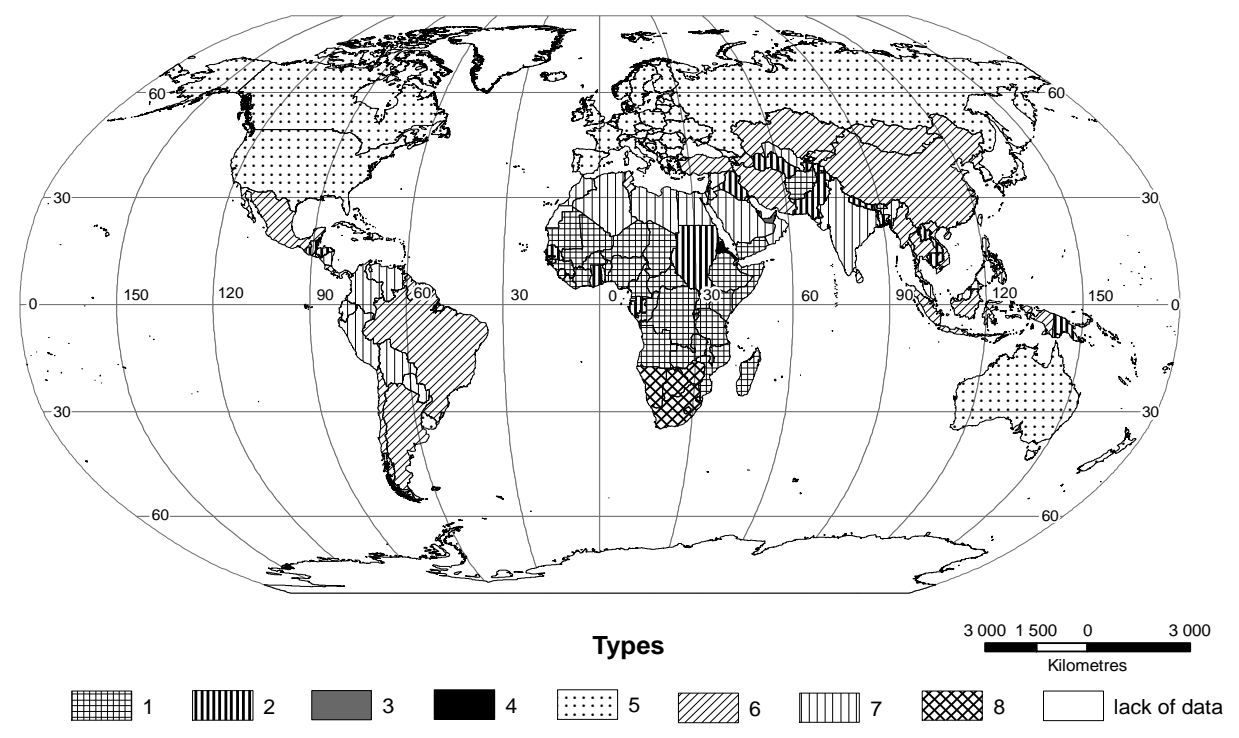

Fig. 6. Demographic spatial typology of the world population

Type 2 - high birth rate and low mortality. Type 2 includes less countries (24) than the previous one. It includes developing countries spread throughout different continents. Populations of those countries display high natural increase resulting from high birth rate and low mortality with a subsequent low migration net ratio which limits annual population growth. At the same time, the age structure of the population features a high share of children and a relative 
shortage of adults and elderly people which results in low demographic ageing. Another distinctive feature of this type is excess mortality among women.

Type 3 -exceptionally high population growth and migration net and record breaking masculinisation of the population. This type is represented by only two small highly-urbanised oil-producing countries located on the Persian Gulf (Qatar and UAE). They display exceptionally high migration net and the related exceptionally high masculinisation of the population and very dynamic demographic growth. At the same time, birth and mortality rates are rather low, however, the average number of family members is high. As a result of high migration net rate, another typical phenomenon is a very high share of adults with an exceptionally low share of elderly people and a small share of children which in turn conditions small demographic dependency and low level of population ageing.

Type 4-high annual population growth ratio convergent with high migration net and rather high natural increase. This type includes only four scattered countries with small populations and low levels of urbanisation (Belize, Eritrea, East Timor and Vanuatu) which display very high annual population growth and migration net. At the same time, there is high natural increase formed in conditions of high birth and fertility and the resulting high share of children and low share of adults and elderly people. Finally, low average life expectancy of both men and women is another distinctive feature of this type.

Type 5 - very high demographic ageing ratio and very long average life expectancy of men and women. This is the most common type in the world. It is represented by 50 highly urbanised countries with developed economies. They form a virtually solid zone stretching from North America through Western, Northern, Southern and Eastern Europe and Russia to South Korea and Japan and even Australia and New Zealand. Their distinctive features include very high demographic ageing convergent with high life expectancy of both women and men with excess mortality of men. At the same time, they display very low natural increase resulting mainly from low birth rate but with very low infant mortality rate. Other characteristic features include low total fertility rate, strong dominance of small families and high share of adults.

Type 6 - high share of adults with low natality and fertility ratios and low mortality. This type is common in many (36) countries of Eastern, Central and South-Eastern Asia as well as in Latin America, generally except the Andes region. Its main features include high share of adults and a relatively high life expectancy of both men and women with a significantly marked excess mortality of women. Additionally, high parity and low demographic dependency are specific for this type. This is accompanied by low mortality and birth rates with small migration net which conditions limited demographic growth. 
Type 7 - dominance of large families with concurrent strong masculinisation. Type 7 is typical for many (29) countries of Northern Africa, Western and Southern Asia as well as for South American countries located in the Andes. Those countries display a dominance of large families convergent with strong masculinisation of the population and low general mortality rate as well as relatively high life expectancy of men and women with significant excess mortality of women. Rather high natural increase and low demographic ageing rate are also visible.

Type 8 - very high total mortality rate with high migration net. The scope of the type is limited to only a few (6) not excessively urbanized South African countries. Its characteristic features include very high total mortality rates and high infant mortality as well as high migration net with very low life expectancy of men and women with clearly visible excess mortality of women. In such conditions, high birth rate and high share of children are not sufficient to ensure adequate natural increase which would guarantee dynamic demographic growth.

\subsection{CONCLUSIONS}

Nowadays, there is a new demographic image of the world. The main goal of the study was to offer a comprehensive discussion of the major elements of the image and to synthesise them. I analysed in detail the spatial distribution of the population, its growth and reproduction as well as the demographic structure. The spatial demographic typology serves as a summary of the study of the problem area. This study is mostly based on reliable demographic information acquired from official publications of individual countries, international organisations and institutions. Within the course of the study, I refer to analyses and diagnoses of the world demographic situation on which many researchers focus.

The study proved that the demographic overview of the world today is very diverse. This is illustrated in a generalised form by the developed spatial typology of the populations of countries (184) which was founded on 19 demographic features. They offer comprehensive illustration of the demographic situation taking into consideration the spatial structure of the population, permanent migrations, demographic development and natural movement and the structure of the population according to sex and age. I developed the typology using the $k$-means clustering method identifying eight clusters associated with country types. I derived the names of specific types from their most significant diagnostic features. The list of identified types includes: Type 1 - very high birth and mortality rates. Type 2 - high birth rate and low mortality. Type 3 exceptionally high annual population growth and migration net and record 
breaking masculinisation of the population. Type 4 - high annual population growth ratio convergent with high migration net and rather high natural increase. Type 5 - very high demographic ageing ratio and very long average life expectancy of men and women. Type 6 - high share of adults with low birth and fertility ratios and low mortality. Type 7 - dominance of large families with strong masculinisation. Type 8 - very high general mortality rate with high migration net.

\section{BIBLIOGRAPHY}

Clarke J.I., 1998, Ludność ziemi, Prószyński i S-ka, Warsaw.

Coleman D.A., 2002, Population of the Industrial World - A Convergent Demographic Community?, "International Journal of Population Geography", 8.

Encyklopedia Świat i Polska 2007, 2006, PWN, Warsaw.

Jagielski A., 1974, Geografia ludności, PWN, Warsaw.

Jędrzejczyk D., 2001, Podstawy geografii ludności, WA DIALOG, Warsaw.

Jones H., 1993, Population Geography, PCP, London.

Kaczmarek T., Koralewski T., Matykowski R., 1998, Ludność świata, Wydawnictwo Kurpisz, Poznań.

Kosiński L.,1967, Geografia ludności, PWN, Warsaw.

Kurek S., 2008, Typologia starzenia się ludności Polski w ujęciu przestrzennym, WN AP, Cracow.

Maryański A., 1977, Ludność świata, PWN, Warsaw.

Notestein F., 1945, Population - the Long View [in:] Schultz T. (ed.), Food for the World, Chicago.

Okólski M. (red.), 1990, Teoria przejścia demograficznego, PWE, Warsaw.

Thumerelle R.-J., 1996, Les populations du monde, Natan, Paris.

Urłanis B. (red.), 1966, Ludność świata, PWE, Warsaw.

Van de Kaa D.J., 1987, Europe's Second Demographic Transition, "Population Bulletin”, Vol. 42, No. 1, Population Reference Bureau, Washington, D.C.

Van de Kaa D.J., 2003, The Idea of a Second Demographic Transition in Industrialized

Countries, “The Japanese Journal of Population”, No.1, Vol. 1.

\section{STRESZCZENIE}

\section{STRUKTURA I TYPOLOGIA PRZESTRZENNA LUDNOŚCI WSPÓŁCZESNEGO ŚWIATA}

Współcześnie ukształtował się nowy obraz demograficzny świata. Głównym celem tego opracowania jest wszechstronne naświetlenie jego najważniejszych elementów składowych oraz dokonanie próby ich syntezy. Szczegółowej analizie poddano dystrybucję przestrzenną ludności, jej rozwój i reprodukcję, a także strukturę demograficzną. Podsumowaniem całości badanej problematyki jest przestrzenna 
typologia demograficzna. Praca ta bazuje głównie na informacjach demograficznych pochodzących $\mathrm{z}$ oficjalnych publikacji poszczególnych krajów oraz organizacji i instytucji międzynarodowych. W toku omawianych badań odwoływano się do diagnozy sytuacji demograficznej świata, będącej obiektem zainteresowania wielu badaczy.

Badania te wykazały, że obraz demograficzny współczesnego świata jest bardzo zróżnicowany. W formie uogólnionej obrazuje to opracowana typologia przestrzenna ludności państw (184), którą oparto na 19 cechach demograficznych. Opisują one wszechstronnie sytuację demograficzną, z uwzględnieniem struktury przestrzennej ludności, migracji stałych, rozwoju demograficznego i ruchu naturalnego oraz struktury ludności według płci i wieku. Typologii dokonano przy użyciu taksonomicznej metody K-średnich, wydzielając osiem skupień utożsamianych $\mathrm{z}$ typami państw. Nazwy określonych typów utworzono od ich najbardziej wyróżniających cech diagnostycznych. Lista wyróżnionych typów obejmuje: Typ 1 - bardzo wysokie natężenie urodzeń i zgonów. Typ 2 - wysokie natężenie urodzeń, przy niskiej umieralności. Typ 3 wyjątkowo wysoki przyrost rzeczywisty i migracyjny, przy rekordowo wysokiej maskulinizacji ludności. Typ 4 - duży przyrost rzeczywisty, zbieżny z wysokim saldem migracyjnym i dość dużym przyrostem naturalnym. Typ 5 - bardzo wysoki poziom starzenia demograficznego i bardzo długie trwanie życia kobiet i mężczyzn. Typ 6 wysoki udział ludności dorosłej, przy niskiej dzietności i rodności oraz umieralności. Typ 7 - dominacja dużych rodzin, przy silnej maskulinizacji. Typ 8 - bardzo wysokie ogólne natężenie zgonów, przy dużym natężeniu przyrostu migracyjnego.

Prof. nadzw. dr hab. Jerzy Dzieciuchowicz

Katedra Gospodarki Przestrzennej i Planowania Przestrzennego Wydział Nauk Geograficznych, Uniwersytet Łódzki 